\begin{abstract}
In the classic understanding of human rights obligations, the state is considered the primary duty-bearer. Governments, however, are increasingly handing over their function of delivering health services to NGOs. This article argues that because of these new and increasing responsibilities, NGOs should also be seen as duty-bearers required to uphold rights through their services, activities, and principles of operation. Translating human rights norms into practical, measurable activities remains a challenge. We worked with organizations delivering HIV-related services to prisoners and injecting drug users in Malawi and Pakistan. The aim was to develop a simple, practical framework of activities and indicators to provide accountability standards against which NGOs could be held accountable for progressively realizing the rights of their clients.
\end{abstract}

Selon l'interprétation classique des obligations en matière de droits de l'homme, l'état est considéré comme le responsable principal à leur égard. Cependant, les gouvernements déchargent de plus en plus leur rôle d'administration des soins de la santé publique sur des ONG. Dans cet article, nous faisons valoir que du fait de leurs nouvelles responsabilités croissantes, les ONG devraient également être considérées comme responsables et tenues de respecter les droits de l'homme dans leurs services, leurs activités et leurs principes opératoires. Traduire les droits de l'homme en activités pratiques et mesurables reste toutefois un défi. Nous avons travaillé aux côtés d'organisations offrant des services concernant le VIH à des prisonniers et consommateurs de drogues par voie intraveineuse au Malawi et au Pakistan. L'objectif était de développer un cadre simple et pratique d'activités et d'indicateurs afin d'établir des normes de responsabilité selon lesquelles les ONG peuvent être tenues responsables du respect progressif des droits de leurs clients.

En el entendimiento clásico de las obligaciones con respecto a los derechos humanos, se considera que el estado es el principal portador de tales obligaciones. Sin embargo, los gobiernos están cediendo cada vez más su función de suministrar servicios de salud a organizaciones no gubernamentales. En este artículo se argumenta que debido a estas responsabilidades nuevas y crecientes, las organizaciones no gubernamentales deben también ser consideradas como portadoras de obligaciones a las cuales se les exija defender los derechos por medio de sus servicios, actividades y principios de operación. Sin embargo, convertir las normas de derechos humanos en actividades prácticas y medibles persiste como un desafío. En el pasado trabajamos con organizaciones que suministraban servicios relacionados con VIH a prisioneros y a usuarios de drogas inyectadas en Malawi y Pakistán. El objetivo fue crear un marco sencillo y práctico de actividades e indicadores para proporcionar estándares de responsabilidad contra los cuales las organizaciones no gubernamentales podrían ser responsables de satisfacer de manera progresiva los derechos de sus clientes. 


\title{
BALANCING PROTECTION AND PRAGMATISM: A Framework for NGO Accountability in Rights-Based Approaches
}

\author{
Susannah Mayhew, Megan Douthwaite, \\ and Michael Hammer
}

$\mathrm{R}$

ights-based approaches aim to empower people to demand their entitlements, promote equity, and challenge discrimination. This includes holding duty-bearers accountable for fulfilling direct obligations to themselves, and those they are responsible for, under standards of due diligence. ${ }^{1}$ While in the classic understanding of human rights, the state is considered to be the primary duty-bearer, governments are increasingly handing over their function of delivering health services to non-state actors, including nongovernmental organizations (NGOs). The state must retain ultimate responsibility for respecting, protecting, and fulfilling human rights. ${ }^{2}$ NGOs, however, especially those claiming to be rights-based in their operations, should also be seen as duty-bearers, upholding rights through their services and activities - even if this requires challenging state policies and their implementation. Many sexual and reproductive health NGOs have long claimed to uphold rights-based approaches in their services. Indeed, sexual and reproductive health advocates have been at the forefront of advances in defining rights-based approaches to health, manifest in the language of the Cairo and Beijing Programs of Action and the International Planned Parenthood Federation's Charter on Sexual and Reproductive Rights. ${ }^{3}$

Susannah Mayhew, MA, PhD, is Lecturer in Health Policy and Reproductive Health, Centre for Population Studies, London School of Hygiene and Tropical Medicine, London, United Kingdom. Megan Douthwaite, Msc, is a freelance consultant in sexual and reproductive health. Michael Hammer, Dipl. Geogr., is Executive Director of The One World Trust. Please address correspondence to the authors at susannah.mayhew@lshtm.ac.uk.

Copyright (c) 2006 by the President and Fellows of Harvard College. 
The reality for many NGOs, however, is that they often fail to fulfill their commitments to a rights-based approach in their actions. Many lack knowledge of international human rights law and the role of national policies. Many also are unaware of how to interpret sexual and reproductive rights at a service delivery level or how to implement a rights-based approach within their modes of operation. The problems are exacerbated when NGOs work with marginalized groups (for example, injecting drug users, prisoners, and commercial sex workers), groups for whom service delivery is often driven more by a paternalistic approach than proactive support for the "rights" of the clients. Further impediments have been created by a spate of US funding policies that impose effective "gags" on the realization of rightsbased approaches in the provision of comprehensive sexual and reproductive health services. 4,5

The rights contained in international treaties are continually re-interpreted through the work of the treaty monitoring bodies; nevertheless, they are not easily translated into practical activities and measures for rights-based reproductive and sexual health service delivery. Both human rights advocates and health practitioners have been slow to respond to the challenge of making the progressive realization of social, cultural, and economic rights, including the right to health, a reality. This includes a failure to take stock of the changing service-provision climate in which NGOs are increasingly responsible for health care, and of the implications of these changes for the responsibility of NGOs to realize rights. ${ }^{6}$

We accepted this challenge and worked with NGOs delivering HIV-related services to prisoners and injecting drug users in Malawi and Pakistan, respectively. The aim was to develop a simple, practical framework of activities and indicators promoting a rights-based approach to health service delivery. It is hoped that the framework can help organizations become more consistent in their rights-based activities, more conscious of rights frameworks, more accountable, and, ultimately, more effective. This proposed framework is applicable both to NGOs and public sector service providers.

This effort is part of wider research we are conducting at the London School of Hygiene and Tropical Medicine in 
collaboration with partners to develop benchmarks for improving NGO accountability and effectiveness in the delivery of sexual and reproductive health services. Given the political sensitivities that surround the field of sexual and reproductive rights, and the frequently controversial relationship in some countries between the state and NGOs who work with marginalized groups in this area, we present anonymized data. In this article, we illustrate the application of the framework in AIDS-prevention services for marginalized groups and draw conclusions for a comparative analysis.

\section{Rights-Based Public Health for Vulnerable Groups}

Public health interventions for vulnerable groups are most effective if they also succeed in being rights-based and in respecting, protecting, and fulfilling the rights of people already marginalized by society. ${ }^{7}$ If services providing HIVrelated prevention and care to commercial sex workers or injecting drug users do not protect the dignity and confidentiality of their clients, they risk driving these already hard-to-reach groups underground. In addition, services that do not pay attention to rights may result in future violations of the rights of clients. For example, unintentionally contributing to their identification may result in police harassment and incarceration. ${ }^{8}$ Once in prison, vulnerability to HIV infection is increased if, as is usually the case, there are no condoms and no clean syringes. ${ }^{9}$

In Indonesia, Nepal, and elsewhere in Asia, the HIV epidemic is believed to have spread because appropriate measures were not taken to reach and protect injecting drug users. ${ }^{10}$ In Thailand, the government has been praised for a highly successful "100\% condom" campaign, which is intended to protect sex workers as well as their clients from infection. At the same time, however, the government's response to injecting drug users has included a vicious "war on drugs," resulting in arbitrary arrests, extrajudicial killings, and disappearances, all targeting the drug-using community. ${ }^{11}$

The detrimental effects of this strategy are already being documented. Injecting drug users are going underground; they no longer seek or carry clean needles (to be found with a needle increases the length of imprisonment); 
if incarcerated, they face overcrowding and poor sanitary conditions, and almost certainly high levels of stigma, leading to beatings, rape, and perhaps also higher-risk drug habits. ${ }^{12}$ Among prisoners, using drugs or not, HIV levels are often twice those of the general population. ${ }^{13}$ Organizations working with injecting drug users and prisoners agree that the only way to reduce HIV prevalence among them is to work with these groups respectfully, protect their rights, and ensure they are not subjected to further stigmatization, harassment, or abuse. 14

\section{Country Contexts and Activities}

Malawi has had a multiparty democracy since 1995. The former president, Hastings Kamuzu Banda, however, has retained significant political influence. Years of brutality during his authoritarian government have left people with a general wariness toward criticizing government or tackling corruption. ${ }^{15}$ The independent press is frequently under attack from the government. ${ }^{16}$

Our study partner there was a national NGO delivering sexual and reproductive health services to men, women, and adolescents. Their services include information on and provision of a range of contraception, safe abortion procedures, and the proposed addition of voluntary counseling and testing services (VCT) for HIV/AIDS. The NGO has had considerable experience in quality of care and reproductive rights (including adolescent access to contraception and abortion). Of most interest here is its work with prisoners, who are a particularly neglected group in Malawi, and among whom HIV prevalence is more than twice that in the general population (see Table 1). Overcrowding, poor health facilities, sexual activity, and rape, especially of minors, are common. ${ }^{17}$ The organization currently works with prisoners in 23 prisons, providing them basic health services, free treatment for sexually transmitted infections (STIs), and HIV information.

Pakistan is a federal republic but has experienced significant periods under military rule. The Constitution includes provisions for the use of Islamic law (including shari'a courts) in certain areas of criminal and civil law, and the military and the Islamic clergy exert significant political influence. Human 


\begin{tabular}{|l|r|r|}
\hline Indicators & Malawi $^{\star}$ & Pakistan $^{\star \star}$ \\
\hline Total population & $11.9 \mathrm{mil}$ & $159.0 \mathrm{mil}$ \\
\hline Women using modern contraception (\%) & 22 & 24 \\
\hline Level of HIV/AIDS in Men (\%) & 14.7 & 0.2 \\
\hline Level of HIV/AIDS in Women (\%) & 17.7 & 0.0 \\
\hline Estimated level of HIV in prisoners (\%) & $40^{\star \star \star}$ & - \\
\hline Estimated level of HIV in injecting drug users (\%) & - & 7.6 \\
\hline Current use of male condoms (\%) & 11.4 & 4.2 \\
\hline
\end{tabular}

Sources:

* Demographic and Health Survey Malawi, 2000; UNAIDS 2004 Malawi Situation Analysis.

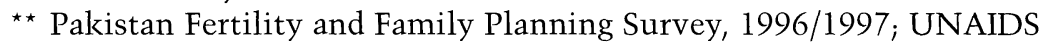
2004 Pakistan Situation Analysis.

${ }^{\star \star \star}$ University of Pretoria, 2004.

Table 1. Selected Sexual Health Indicators for Malawi and Pakistan, 2004.

rights abuses against women, children, and religious minorities at the hands of state and non-state actors are common but are largely ignored by the government. Vulnerable groups, such as injecting drug users and sex workers, are treated with high levels of discrimination and contempt and are subject to frequent harassment and incarceration by the authorities. ${ }^{18}$ There are also severe restrictions on freedom of expression in many parts of the country. ${ }^{19}$

Our study partners in Pakistan were eight small, local NGOs who were all registered with national and provincial authorities. Each NGO was developing projects to offer HIVprevention services for populations believed to be at high-risk (injecting drug users, sex workers, truck drivers, and street youth). Most of these NGOs were newly established, with little capacity or experience in human rights, or sometimes even in HIV/AIDS. Although national HIV prevalence in Pakistan is low (see Table 1), injecting drug users are considered a particularly vulnerable population. ${ }^{20}$ In addition, in- 
jecting drug users are a key group for transmission of hepatitis $\mathrm{C}$, which can also be fatal. The focus here is on the three Pakistani NGOs that are working with injecting drug users.

\section{A Rights-based Framework for Service-Delivery NGOs: The Process}

In both Malawi and Pakistan, we worked with local NGO partners to:

- Review the national policies on sexual and reproductive health that were relevant to the work of the organization;

- Review the institutional policies of each organization relevant to rights-based approaches;

- Analyze current practices in terms of implementing rights-based approaches in existing services;

- Conduct a training on rights-based approaches and their application to sexual and reproductive health service delivery;

- Develop a rights-based approach activities checklist based on:

- Malawi - interviews with staff at different levels of the organization (from management to clinic provider) and observation of work;

- Pakistan - staff review of current activities and identification of proposed rights-based activities relating to HIV prevention; and

- Develop rights-based indicators and plans for monitoring and evaluation based on the rights-based checklist and the SMART principles for indicator development. (SMART is an acronym for specific; measurable; appropriate/achievable; realistic/relevant; time-bound.)21

Our review of organizational policies and practices and an assessment of the capacities of each NGO in both of these countries led us to develop the following generic framework to implement and monitor rights-based activities at an organizational level. The aim of the framework was to make the rights-based discourse accessible and practical in a way that health NGOs could make it operational. We took core rights principles (equality, non-discrimination, participation, and so forth) and drew on the work of both Rebecca Cook and 
Paul Hunt to define simple, practical rights-based activities for sexual and reproductive health providers. ${ }^{22}$

The framework consists of four components, further elaborated below:

1. Engage with international and national policies and laws to uphold rights to health and health care:

a. Monitor, review, and critique policy and legal documents;

b. Document and use medical and epidemiological evidence;

c. Network with legal, advocacy, and human rights specialists to influence policy adoption and/or implementation; and

d. Develop strategies for and conduct advocacy around key policy issues.

2. Ensure respect for client rights and provision of quality of care at the service-delivery level:

a. Develop a client rights charter;

b. Ensure free and informed decision-making;

c. Provide privacy and confidentiality;

d. Ensure non-discrimination;

e. Provide safe, competent service delivery; and

f. Obtain support of staff.

3. Identify and address underlying inequalities related to access to and use of health care services, including gender, poverty, and vulnerability:

a. Identify staff issues; and

b. Identify community issues.

4. Develop, monitor, and analyze context-specific indicators based on standard monitoring/evaluation framework. Indicators reflect the activities under components 1-3 and are to be reported and reviewed regularly.

Engage with Policy. The first framework element is to engage with policy. A key element of a rights-based approach is the use of policy to hold duty-bearers to account. As noted earlier, even though the state is the primary duty-bearer, this framework also views NGOs aiming to deliver "rights-based" services and activities as duty-bearers. In our view, NGOs' obligations include engaging with policies that affect their areas of work and 
challenging these policies or their implementation where they impede the realization of rights. Thus, implementing a rightsbased approach requires various policy-level activities. These include regular assessment by the organization's managers of when the organization should advocate changes to existing national policies and when the organization should promote better implementation of national and international policies to uphold rights that are already legally enshrined.

Four types of activities are to be undertaken in this component. First, monitor new policies as they emerge and consider their implications for the organization's work. Second, collect data on health indicators (for example, on rape, unsafe abortion, and prevalence of HIV/AIDS) in a way that could be used as evidence to uphold rights issues through advocacy. Data must be disaggregated by sex and other variables, such as socio-economic characteristics and ethnic group (see discussion of indicators below). Third, service delivery NGOs are not advocacy or legal specialists; therefore, it is important that they network with other organizations specializing in complementary areas such as legal action and human rights advocacy. Policies can be influenced and rights upheld more effectively in collaboration with other groups. Finally, NGOs must advocate or represent rights issues in appropriate fora and at meetings relevant to all levels of the policy process.

Use Rights-based Approaches to Service Delivery. The second framework component, a rights-based approach to service delivery, consists of three main areas of activity. First, service delivery must uphold and respect client rights, which includes development of a client rights charter. While such voluntary charters run the risk of being overly ambitious and unenforceable, key elements can be concretely implemented. In particular, NGOs should develop procedural safeguards for privacy, confidentiality, and non-discrimination. Second, they should deliver safe and competent services. This relates to quality of care, for which standards and guidelines have long been in existence for sexual and reproductive health. Quality of care guidelines encompass choice of method, information given to clients, technical competence, interpersonal relations (including confidentiality), mechanisms to encourage continuity of service use, and appropriate constellation of services.23 
Finally, this component of the rights framework requires organizations to ensure appropriate support for staff to be able to deliver quality services and properly uphold rights.

Address Underlying Inequalities. The third framework component is to identify and address underlying inequalities in terms of access to services (based on location, social/cultural factors, and economic access). Identifying and addressing underlying inequalities that may affect access to services involves ongoing review and analysis, monitoring, and reporting data on the organization's efforts to identify areas for research (which may be outside the organization's own capacity to conduct), as well as developing strategies to respond to emerging issues. This enables an organization to identify which groups it is, or is not, reaching. Analysis of both staff and community concerns enables assessment of barriers that limit equitable access to services for some groups and allows an organization to consider what institutional responses can be put in place. Such barriers include gender inequalities, poverty, and social marginalization. Critically, this component must include participation of target communities in research development and feedback on findings. Participation, both of communities and service personnel, is important as an end in itself and to achieve "ownership" of research and resulting policies and programs.

Utilize Context-specific Indicators to Assess Changes. The fourth framework component is to develop, monitor, and analyze context-specific indicators to assess dimensions of change in policy, service delivery practice, equality, and participation, which are fundamental to the implementation of rights-based approaches. Collection, analysis, and dissemination of data are central components of rights-based approaches, not merely additions to the "real work." 24 In addition to providing information regarding unfulfilled rights in order to put pressure on duty-bearers, the collection and dissemination of data should also encourage a culture of accountability and participation in mainstreaming rights-based approaches among implementing partners. An organization's internal policies and practices must also reflect human rights principles. Thus, a rights-based 
approach requires that attention be paid to the conduct of the organization itself-what and how activities are implemented (process indicators) - and not simply a focus on what is achieved (impact or outcome indicators).

The first step toward developing appropriate rights-based indicators is to clarify the goal and objectives of the project or program using "rights" language and to develop activities to achieve these. Tools that are useful in clarifying project structure and logic include the logical framework approach (defining activities-output-purpose-goal) and the monitoring and evaluation framework (defining inputs-process-outputs-outcomes-impact), now widely used by UNAIDS and its partners. ${ }^{25}$

The second step is to turn broad goals and objectives into measurable and practical standards, or indicators, which can be used to monitor and hold duty-bearers to account, as well as to measure change in policy, service delivery, equity in outcomes, and participation. It is impossible to measure everything; therefore, the challenge is to identify key indicators to capture the essential rights issues relevant to a particular program and do this at all appropriate stages. Paul Hunt, in his role as the Special Rapporteur on the Right to Health, considers rights-based indicators to be an important component of a rights-based approach and defines them at the structure, process, and outcome level. ${ }^{26}$

Figure 1 shows how these different requirements are amalgamated in the framework we used to assist with clarifying goals, objectives, and indicators. Although we covered each element of the framework in our work in Malawi and Pakistan, for this article we focus on the role of policy and related indicators in Malawi, since our application of the framework identified policy activities as a priority. In Pakistan, where NGO capacities were extremely weak, the focus is on the services provided and the development of monitoring and evaluation indicators to help ensure that rights-based approaches are implemented.

\section{Malawi: NGO Obligations to Hold Government Accountable for the Sexual Health of Male Prisoners}

\section{Identifying Vulnerable Groups and Their Service Needs}

The NGO in Malawi had identified prisoners as a vulnerable and marginalized group that lacked proper access to 


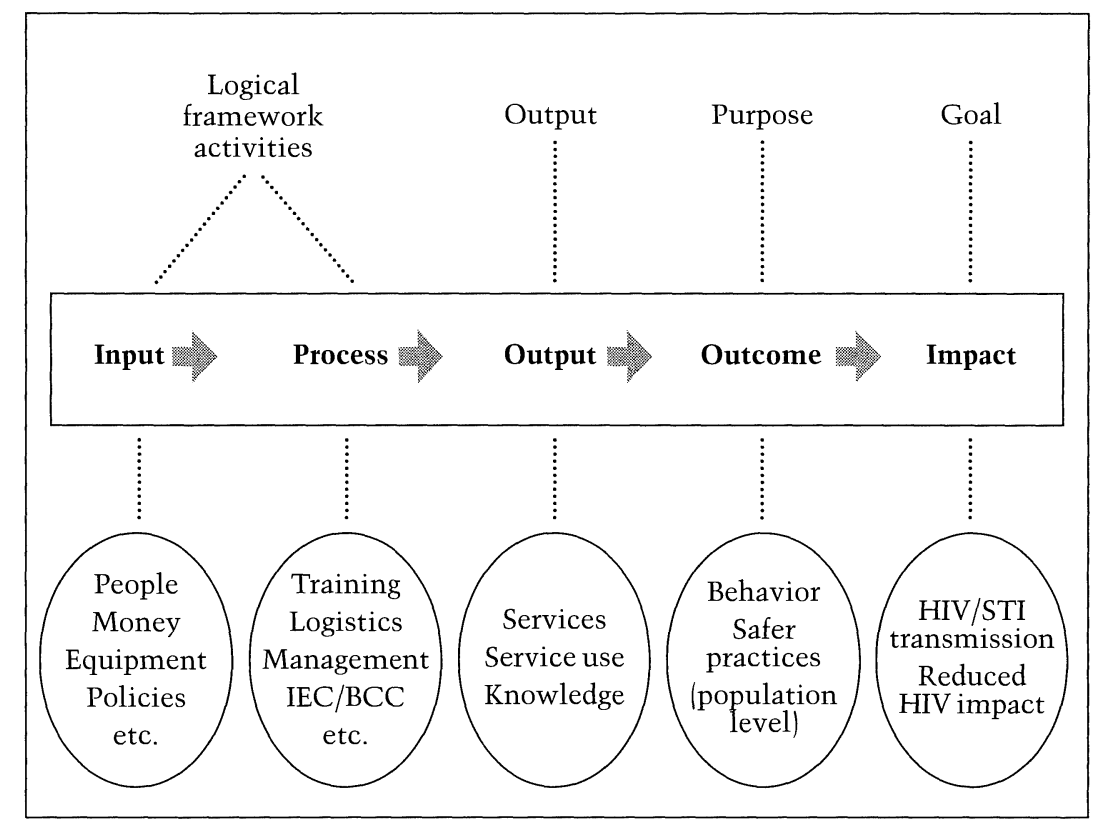

Figure 1. Examples of Frameworks to Assist with Clarifying Goals, Objectives, and Indicators.

health services. The project aimed to provide services to prisoners in line with their rights to health and non-discrimination. The 23 prisons in which the NGO works are mostly men-only; some are mixed (but in separate quarters), and some are for juvenile offenders who are often integrated into adult cells. The NGO reaches over 5,000 mostly male prisoners of Malawi's total prison population of 8,800. Prison health facilities in Malawi are of notoriously poor quality, and several reports have recommended urgent improvements, including the training of prison staff in the principles of "rights" and in HIV/AIDS prevention and counseling. ${ }^{27}$ It appears that men are twice as likely to become infected with HIV in prison, where the prevalence is $40 \%$; when released, infected prisoners would therefore represent a major risk to the spread of HIV beyond the prisoner population. ${ }^{28}$ Currently Malawi's prisons provide only a limited range of health services and do not ensure privacy or confidentiality. ${ }^{29}$ The law includes a policy of non-discrimination against HIV-positive prisoners, but unless confidentiality can be assured, prisoners are unlikely to come forward for HIV testing or treatment. 
In recognition of the pressing need for basic health services, the NGO had begun to provide basic curative services, free STI treatment and counseling, and HIV/AIDS information and counseling. It has a reputation for delivering quality services and respecting confidentiality in the clinics that it runs for the general population, and this work is now being expanded to prisons. The NGO hopes soon to offer HIV voluntary counseling and testing services, although this will require further training of its staff. The project also provides entertainment, talks, and decontamination of clothes, blankets, and possessions for prisoners. These activities aim to meet some of the prisoners' emotional, psychological, and hygiene needs.

The NGO's existing prison services have proven popular, and through their work over the past three years, the staff have found that prisoners want more information on HIV infection and prevention, as well as access to condoms. At present the NGO is barred from providing condoms in allmale prisons because sex between men is illegal, and the prison authorities claim that condom provision would encourage same-sex relationships. To address concerns about the spread of HIV in prison, the NGO had considered advocating for the legalization of same-sex relationships. In the country context of Malawi, however, society in general is very conservative and, as in most African societies, male-onmale sex is a highly taboo subject. In addition, the Catholic church has a great deal of influence. An open advocacy strategy was therefore considered to be inappropriate at the present time.

\section{Using Policy to Hold Governments Accountable}

A brief review of national and international policies relating to HIV/AIDS and rights of vulnerable groups was undertaken using the categorization of rights suggested by Cook et al. $30 \mathrm{~A}$ review of rights drawn from the international human rights documents that Malawi has ratified shows that there are many provisions that could be actively used by NGOs in the country to promote prisoners' health-related and other rights. Table 2 gives an overview and highlights those rights that could be used to improve the situation of prisoners who are at risk of HIV because of lack of access to condoms. 


\begin{tabular}{|c|c|c|c|c|c|c|c|}
\hline \multirow[b]{3}{*}{ Rights Covered } & \multicolumn{7}{|c|}{ International Treaties (full names below) } \\
\hline & ICCPR & ICESCR & CEDAW & $\begin{array}{l}\text { Rights } \\
\text { of Child }\end{array}$ & $\begin{array}{l}\text { African } \\
\text { Charter }\end{array}$ & Cairo & Beijing \\
\hline & & & & & & & \\
\hline \multicolumn{8}{|c|}{ 1. Life, survival, and security } \\
\hline Life \& survival & $\mathbf{Y}$ & & & $\mathbf{Y}$ & $\mathbf{Y}$ & $\mathbf{Y}$ & $\mathbf{Y}$ \\
\hline $\begin{array}{l}\text { Liberty \& } \\
\text { security of the } \\
\text { person }\end{array}$ & $\mathrm{Y}$ & & & $\mathrm{Y}$ & $\mathrm{Y}$ & $\mathrm{Y}$ & $\mathrm{Y}$ \\
\hline $\begin{array}{l}\text { Freedom from } \\
\text { torture, cruel/ } \\
\text { degrading treatment }\end{array}$ & $\mathbf{Y}$ & & & $\mathbf{Y}$ & $\mathbf{Y}$ & $\mathbf{Y}$ & $\mathbf{Y}$ \\
\hline \multicolumn{8}{|c|}{ 2. Reproductive self-determination } \\
\hline Maternity protection & & Y & $\mathrm{Y}$ & $\mathrm{Y}$ & $\mathrm{Y}$ & $\mathrm{Y}$ & $\mathrm{Y}$ \\
\hline $\begin{array}{l}\text { Marry \& found } \\
\text { family }\end{array}$ & $\mathrm{Y}$ & $\mathrm{Y}$ & $\mathrm{Y}$ & & $\mathrm{Y}$ & $\mathrm{Y}$ & $\mathrm{Y}$ \\
\hline Private $\&$ family life & $\mathrm{Y}$ & $\mathrm{Y}$ & $\mathrm{Y}$ & $\mathrm{Y}$ & $\mathrm{Y}$ & $\mathrm{Y}$ & $\mathrm{Y}$ \\
\hline \multicolumn{8}{|c|}{ 3. Health and benefits of scientific progress } \\
\hline $\begin{array}{l}\text { Highest attainable } \\
\text { standard of health }\end{array}$ & & $\mathrm{Y}$ & $\mathrm{Y}$ & $\mathrm{Y}$ & $\mathrm{Y}$ & $\mathrm{Y}$ & $\mathrm{Y}$ \\
\hline Procedural fairness & $\mathbf{Y}$ & & $\mathbf{Y}$ & $\mathbf{Y}$ & $\mathbf{Y}$ & $\mathbf{Y}$ & $\mathbf{Y}$ \\
\hline $\begin{array}{l}\text { Benefits of scientific } \\
\text { progress }\end{array}$ & & $\mathrm{Y}$ & & & $\mathrm{Y}$ & $\mathrm{Y}$ & $\mathrm{Y}$ \\
\hline \multicolumn{8}{|c|}{ 4. Sexuality, non-discrimination, and respect for difference } \\
\hline Sex \& gender & $\mathrm{Y}$ & $\mathrm{Y}$ & $\mathrm{Y}$ & $\mathrm{Y}$ & $\mathrm{Y}$ & $\mathrm{Y}$ & $\mathrm{Y}$ \\
\hline Marital status & $\mathrm{Y}$ & $\mathrm{Y}$ & $\mathrm{Y}$ & & $\mathrm{Y}$ & $\mathrm{Y}$ & $\mathrm{Y}$ \\
\hline Age & $\mathrm{Y}$ & $\mathrm{Y}$ & & $\mathrm{Y}$ & $\mathrm{Y}$ & $\mathrm{Y}$ & $\mathrm{Y}$ \\
\hline Race \& ethnicity & $\mathrm{Y}$ & $\mathrm{Y}$ & & $\mathrm{Y}$ & $\mathrm{Y}$ & $\mathrm{Y}$ & $\mathrm{Y}$ \\
\hline Sexual Orientation & $\mathbf{Y}$ & $\mathbf{Y}$ & & $\mathbf{Y}$ & $\mathbf{Y}$ & $\mathbf{Y}$ & $\mathbf{Y}$ \\
\hline \multicolumn{8}{|c|}{ 5. Right to information, education, and decision making } \\
\hline $\begin{array}{l}\text { Receive \& } \\
\text { impart information }\end{array}$ & $\mathrm{Y}$ & & $\mathrm{Y}$ & $\mathrm{Y}$ & $\mathrm{Y}$ & $\mathrm{Y}$ & $\mathrm{Y}$ \\
\hline Education & & $\mathrm{Y}$ & $\mathrm{Y}$ & $\mathrm{Y}$ & $\mathrm{Y}$ & $\mathrm{Y}$ & $\mathrm{Y}$ \\
\hline $\begin{array}{l}\text { Freedom of thought, } \\
\text { conscience, religion }\end{array}$ & $\mathrm{Y}$ & & $\mathrm{Y}$ & & $\mathrm{Y}$ & $\mathrm{Y}$ & $\mathrm{Y}$ \\
\hline \multicolumn{8}{|c|}{$\begin{array}{l}\text { Note: rights that could be applied to prisoners at risk of HIV because of lack of access to } \\
\text { condoms are highlighted in bold. }\end{array}$} \\
\hline \multicolumn{8}{|c|}{$\begin{array}{l}\text { ICCPR = International Covenant on Civil and Political Rights; ICESCR = International } \\
\text { Covenant on Economic, Social, and Cultural Rights; CEDAW =Convention on the Elimination } \\
\text { of All Forms of Discrimination Against Women; Rights of Child = Convention on the Rights of } \\
\text { the Child; African Charter = African Charter on Human and People's Rights; Cairo = Cairo } \\
\text { Programme of Action of the International Conference on Population and Development, Cairo } \\
\text { 1995; Beijing = Beijing Platform of Action of the 4th UN Conference on Women, Beijing 1995. }\end{array}$} \\
\hline
\end{tabular}

Table 2. Sexual and Reproductive Rights Covered by International Treaties Ratified by the Government of Malawi. 
In addition, national legislation and policies relating to HIV/AIDS uphold the rights of prisoners. The National AIDS Strategy (2004), citing the National AIDS Programme, explicitly states that prisoners are recognized as being especially vulnerable to STI/HIV infection and that they have a "right to preventive services (including condoms)." Moreover, the Strategy states that homosexuals should be "treated without discrimination" in regard to access to health care, including for HIV/AIDS. ${ }^{31} \mathrm{~A}$ number of recent national and international reports have also put pressure on Malawi's government to improve the health of prisoners and, in particular, to reduce the spread of HIV. 32

The NGO had not been aware of these policy provisions. When discussing how to use the policies to hold their own government to account, staff were reluctant to undertake high-profile advocacy because of their historically unstable relationship with the government.

In an important move in January 2005, however, the Malawi Human Rights Resources Centre called for discussion on the legalization of same-sex relationships, in recognition that current laws constitute serious discrimination against a minority. 33 This shows not only that it is possible to raise controversial issues in public and advocate change but also that there is a significant potential for NGOs to develop alliances and reach their aims through networking activities.

Using the framework, we discussed the options relating to policy actions and identified a number of activities that the NGO did feel comfortable undertaking. These included documenting STI and HIV infection rates in prisoners (through anonymous service records stating the numbers of patients treated or tested); networking with other local advocacy groups to share data and promote the right of prisoners to have access to condoms; and lobbying the government in closed meetings to properly implement the existing laws protecting prisoners' rights. The NGO already has representation on District Health Committees and the National Reproductive Health Committee within the Ministry of Health. This puts it in an excellent position to pass on key information and findings on health and rights issues relating to prisoners and to draw policy-makers' at- 
tention to the current deficiencies in services and implementation of existing laws and guidelines. In closed meetings at the national level, the NGO can also promote the rights of prisoners by referring politicians to the Malawi government's obligations under the international human rights treaties that it has ratified.

One immediate action identified was for the NGO to ask someone from the National AIDS Commission to talk to prison authorities about the need to allow delivery of condoms in prisons, in line with the National AIDS Strategy. Given current political realities, it was agreed that information that could be conveyed should include the fact that sexual activity between men in prisons has been documented and cannot be ignored; that there is a $40 \% \mathrm{HIV}$ prevalence rate in prisons, which potentially poses a serious threat to the nation at large /therefore extra measures to prevent HIV transmission in prisons are essential to fighting the epidemic); and that there is no evidence that the promotion of condoms encourages sexual activity that is not already taking place. 34

Policy-related activities need to be monitored regularly to ensure that they occur. Selection of indicators must be context-specific and follow SMART criteria (see the "monitoring and evaluation" discussion in the Pakistan case study that follows). Suitable indicators for the work of the Malawi organization were identified as:

- Determination as to whether services are compliant with policies relevant to prisoners' health, especially the National AIDS Strategy;

- Number of prison clients, disaggregated by age, sex, and marital status, attending each service (STI treatment, HIV counseling/testing, and so forth);

- $\quad$ STI/HIV prevalence by age and sex, percent in prison clients;

- Number and level of links made, meetings held, and resources shared with other service providers and advocacy groups, especially those engaged in human rights and legal activities; and

- Number and level of rights advocacy events conducted. 


\section{Lessons from Malawi}

In Malawi, prisoners' rights to access condoms and health care are explicit in national policies. Yet prison authorities are still obstructive, citing the illegality of same-sex activity as the reason why condoms cannot be distributed to prisoners, even in the face of rampant rates of HIV infection. The NGO providing STI treatment and HIV information and counseling, while contributing a valuable service, has an obligation in implementing a rights-based approach that includes challenging the reasons for non-distribution of condoms. Prior to the application of the rights-based framework, the NGO had been doing excellent work in providing quality and confidential services, but was reluctant to step beyond this to address and challenge the limitations or obstructions it faced in furthering its activities. For NGOs, application of a rights framework must include a willingness and ability to hold their own governments accountable - in partnership with others when necessary. Where it may be risky for them to engage in high-profile advocacy, NGOs can network with other groups, like the Malawi Human Rights Resources Centre, and share information on violations and approaches to address them.

\section{Pakistan: Monitoring and Evaluation to Protect the Rights of Injecting Drug Users}

\section{Identifying Vulnerable Groups and Their Service Needs}

All the NGOs with whom we are working in Pakistan have identified groups within Pakistani society that are highly marginalized and vulnerable because of their circumstances (homeless or migrants) or their activities (sex work; injecting drugs). This case example is taken from those NGOs working with injecting drug users, who are a highly stigmatized and ostracized group. Injecting drugs is illegal in Pakistan, yet the country has one of the highest recorded rates of use in the world. ${ }^{35}$ It also has an active history of police raids to round up and incarcerate injecting drug users. As in other countries, discrimination and abuse of injecting drug users only serve to push them into higher-risk behavior, including making them reluctant to attend needleexchange programs for fear of being identified. ${ }^{36}$ There is an- 
ecdotal evidence that injecting drug users have been arrested in Pakistan following police raids on NGO offices for information on the identity and whereabouts of users. Once injecting drug users are in prison, their HIV and Hepatitis C infection rates increase significantly because of lack of access to clean needles.

An additional risk, already documented in India, China, and other countries in the region, which underlines the importance of making prevention measures work, is the spread of HIV from infected injecting drug users to their sexual partners. ${ }^{37}$ Research in Indonesia has shown that HIV in injecting drug users can "kick start" an HIV epidemic in the general population (through sexual transmission to their partners) unless prevention programs are in place before HIV levels take off in injecting drug users. ${ }^{38}$ In Pakistan this situation is exacerbated by extremely low levels of HIV awareness or condom use. 39

\section{Protecting Clients through Competent, Confidential Services}

After discussion of the NGOs' current services and practices using the framework, two things became clear. First, the NGOs had no capacity to undertake the policy-related activities in the framework. Second, there were serious problems with the way the NGOs currently provided services to injecting drug users. While NGOs, as duty-bearers, have a responsibility to respect and uphold the rights of those they work with, the local staff had not even the most basic understanding of rights or rights-based approaches to services, including the fact that already vulnerable groups had a right not to be put at further risk through their involvement with the services. We therefore focused on elements two and four of the framework. The first step was to undertake training with the local staff on client rights. This included exercises to highlight why public health measures to reduce HIV in vulnerable groups are actually more effective when they are rights-based.

The NGO staff then considered their own service activities and assessed whether they were effective in terms of both public health and upholding rights. One result that emerged was that the routine recording of names and residences of injecting drug users exposed clients to great risk of 
harassment, arrest, and even incarceration should any of the NGOs be raided by police (which is not uncommon). Using the framework, we explored, with each NGO, the challenges involved in protecting the privacy and confidentiality of vulnerable clients. Through group discussion, it was agreed that the identities of clients would no longer be recorded in a way that could lead the police to identify them - that false names or identity numbers would be used, and no residence information would be recorded.

Another area of concern was the highly paternalistic approach of many of the NGO workers toward their clients. We discussed how each NGO could better achieve participation with its client group, with a view to improving both the services and their uptake. Suggested activities included involving injecting drug users in a participatory way in assessing existing services (so that injecting drug users' needs are fully considered), in deriving conclusions from the assessment data gathered, in designing the program, and even in managing and carrying out program activities such as peer education.

\section{Monitoring and Evaluation to Ensure Rights-based Service Delivery}

Given the very weak capacity of these NGOs to deliver rights-based services and the probability that activities would not become more rights-based unless reportable indicators were established, a simple monitoring system was developed. A detailed training on the principles and importance of monitoring and evaluation (M\&E) was provided and, in consultation with each partner, a set of indicators and reporting system developed. We used the logical framework to understand the logic of each project, clarifying the goals and objectives and identifying basic indicators. The monitoring system and indicators had two functions: 1) to allow the NGO to monitor its own conduct in terms of client rights and 2) to collect information for advocacy purposes. In this context, the former function was considered crucial to build capacity and promote a culture of accountability, participation, and equity among NGO partners.

An $M \& E$ framework cannot in itself establish a rightsbased approach to HIV prevention, but by including key indicators in the framework, it can contribute to highlighting rights 
as a basic component of the program and ensure that all projects report on core rights indicators. The rights indicators selected were simple, both in terms of data collection and interpretation requirements. Nevertheless, they contributed important information for strengthening implementation of rights-based approaches. The core set of indicators comprised a combination of explicit rights indicators with more standard reproductive health service delivery indicators, which were selected in relation to different stages of the project cycle. Indicators included:

- Simple activity-based indicators monitoring protection of rights collected through routine service statistics, for example:

- Number of injecting drug users arrested on drug-related crime in the last quarter while participating in project activities;

- Number of clean needles distributed to target group in the last quarter;

- Number of injecting drug users receiving harm reduction interventions in the last quarter (for example, condom distribution and methadone programs);

- Number of injecting drug users receiving services who report satisfaction with these services; and

- Number of injecting drug user advocacy events on HIV and rights conducted at all levels.

- Organizational indicators to monitor capacity improvements/deficiencies, collected through non-routine one-off/annual evaluations; for example:

- Agreed-upon client confidentiality procedures in place;

- Number of staff with knowledge of human rights and the rights of vulnerable clients;

- Percent or number of trained staff working with injecting drug users, by type and sex;

- Linkages with existing Pakistani human rights groups for advocacy; and

- Evidence that injecting drug users are meaningfully involved in program design and implementation.

We worked with our partners to develop clear, explicit guidelines and detailed, context-specific definitions for each indicator, including harm reduction and client satisfaction. 
Many of the indicators were based on those already existing because we saw no merit in reinventing them. ${ }^{40}$ There is a recognized dearth of specific rights-based indicators, however, and a number of initiatives are currently underway to develop them..$^{41}$

\section{Lessons from Pakistan}

Despite the weak capacity of our Pakistani partners, the rights-based framework developed here enabled the protection of clients to be implemented in a pragmatic way. While the result may not be ideal, it does allow even the weakest of organizations to protect basic rights that were not protected before. In particular, the routine use of agreed-upon indicators ensures that NGOs put in place activities and organizational practices that respect basic rights (such as services users' confidentiality). The routine reporting on these indicators helps to promote a culture of accountability and mainstream rights-based approaches within organizations.

\section{Conclusion}

This article argues that NGOs, and indeed all public health service providers, should respect, protect, and fulfill the rights of their clients, particularly those who are already experiencing marginalization or discrimination. The state has ultimate responsibility to ensure the progressive realization of its citizens' right to health and should in no way be absolved of this responsibility. Additionally, however, service delivery NGOs, especially those claiming to be rights-based, should be seen as accountable duty-bearers, whether acting independently or on behalf of a national government. NGOs must ensure their three-way accountability - to government, to their clients, and also to other civil society groups working in this area. Currently, few standards or mechanisms exist to hold NGOs accountable to rights standards. This article presents a simple framework that aims to define a set of "good practice" activities for implementing rights-based approaches in health service delivery. These can also work as benchmarks against which NGOs can be held accountable and improve their effectiveness in making the right to health a reality for their clients.

The Malawi case shows how the framework enabled an NGO with good capacity and sound rights-based service 
delivery to recognize its obligation to move beyond its service focus to challenge underlying discrimination and inaction by the state (in this case, prison authorities and government officials). The framework helped the NGO identify how it could hold government authorities accountable for ensuring full implementation of existing policies upholding the right of prisoners to access condoms to protect themselves from HIV/AIDS.

The Pakistan case was very different because of the extremely weak capacity of the local NGOs. Training in rights principles was necessary to equip staff to assess their existing activities in light of these principles. To ensure that rights-based services were then routinely delivered, it was necessary to develop a simple monitoring framework with indicators to be regularly reported on and reviewed. The indicators reflected the need to ensure basic privacy and confidentiality of already vulnerable groups.

In sum, the rights-based framework that we have developed allows NGOs to identify what they can do within their capacity, what is best done by others, and where they should be linking with others. The use of clear activity checklists and associated indicators helps to institutionalize, benchmark, and mainstream rightsbased approaches. The framework also provides a checklist that allows NGOs to continually reassess their capacity to uphold rights and expand their activities as capacities increase.

Enhancing NGO accountability vis-à-vis rights realization depends on pragmatic translation and application of international rights principles into routine activities. The case studies presented here show the benefit of the framework for enhancing the accountability of NGOs to deliver services that progressively respect, protect, and fulfill the rights of their clients. We believe that, if adopted, the framework could provide a standard against which NGOs can be held accountable by external bodies, including donors and government bodies. This should contribute to rights-based organizations becoming more effective in their work to promote the right to health and progressively realize the rights of their beneficiaries. 


\section{Acknowledgements}

We thank two anonymous reviewers for their insightful comments. This work was partly funded by a grant from the European Union as part of an initiative of Interact Worldwide. The contents of this paper are the sole responsibility of the London School of Hygiene and Tropical Medicine and can under no circumstances be regarded as reflecting the position of the European Union.

\section{References}

1. J. Theis, Rights-Based Monitoring and Evaluation: A Discussion Paper (Save the Children: April 2003). Available at http://www.mande.co. uk/docs/Rights-basedMonitoringAndEvaluation.pdf.

2. The Maastricht Guidelines on Violations of Economic, Social, and Cultural Rights. UN Economic and Social Council, 2000: E/C. 12/2000/13, paragraph 18. Available at http://shr.aaas.org/thesaurus/instrument.php? insid $=95$.

3. United Nations, Population and Development: Programme of Action Adopted at the International Conference on Population and Development, Cairo, September 5-13, 1994 (UN: Department for Economic and Social Information and Policy Analysis, 1995); Platform for Action of the Fourth World Conference on Women, UN Doc. A/CONF.177/20 (1995); International Planned Parenthood Federation, IPPF Charter on Sexual and Reproductive Rights (London: IPPF, 1996).

4. These are the Mexico City Policy, first announced by Reagan in 1984, rescinded under Clinton in 1993, and reinstated by Bush in 2001 - see http://www.whitehouse.gov/news/releases/20010123-5.html - which prevents US funding from going to any organization that delivers abortion or abortion-related services, including counseling and referral for safe abortion; and the President's [US] Emergency Plan for AIDS in Africa (PEPFAR), enshrined in the United States Leadership Against HIV/AIDS, Tuberculosis and Malaria Act (2003) - Public Law 108-25, 22 USC 7601 (23) (2003), which endorses an abstinence-only approach to the prevention of HIV/AIDS and restricts access to condoms except as a "last resort" for "high-risk" groups, such as sex-workers and drug users. PEPFAR also prevents funding from going to organizations refusing to sign a statement that sex work is immoral and illegal. The full text of the Law detailing PEPFAR is available at http://frwebgate.access.gpo.gov/cgi-bin/ getdoc.cgi?dbname=108_cong_public_laws\&docid=f:publ025.108.pdf.

5. See, for example, Human Rights Watch, The Less They Know, The Better: Abstinence-Only HIV/AIDS Programs in Uganda 17/4 (A) (New York: Human Rights Watch, 2005); Human Rights Watch, Ignorance Only: HIV/AIDS, Human Rights and Federally Funded Abstinence-Only Programs in the United States - Texas: A Case Study 14/5 (9) (New York: Human Rights Watch, 2002); R. Marindo, S. Pearson, and J. Casterline, Condom Use and Abstinence Among Young People in Zimbabwe: Which Strategy, Whose Agenda? Working Paper No. 170 (Washington, D.C.: Population Council, 2003).

6. There is a large body of literature on the shifting roles and responsibil- 
ities of NGOs as they become less philanthropic and more business-oriented. Two useful collections are provided in D. Lewis and T. Wallace (eds), New Roles and Relevance: Development NGOs and the Challenge of Change (Hartford: Kumarian Press, 2000); M. Edwards and A. Fowler (eds), Earthscan Reader on NGO Management (London: Earthscan, 2002). Despite increasing mention of "rights" vis-à-vis health in international discourse and a plethora of literature at conceptual and policy levels, there remains a disjuncture between health providers (NGO and state) and human rights advocates, legal structures, and principles. There is still a lack of literature dealing with how health providers employ human rights in practice. One exception is provided in R. Cook, B. Dickens, and M. Fathalla, Reproductive Health and Human Rights: Integrating Medicine, Ethics and Law (Oxford: Clarendon Press, 2003). In their introduction, the authors describe how separated the work of health practitioners and human rights practitioners is. Their book is an attempt to bring these worlds closer. Another valuable exception is the IPPF Charter Facts on Sexual and Reproductive Rights (London: IPPF, 2003). This document gives examples of how their charter rights have been put into practice at field level.

7. World Health Organization, Transforming Health Systems: Gender and Rights in Reproductive Health - A Training Curriculum for Health Programme Managers, WHO/RHR/01.29 (Geneva: WHO, 2001).

8. Monitoring the AIDS Pandemic (MAP), AIDS in Asia: Face the Facts A Comprehensive Analysis of the AIDS Epidemics in Asia (MAP: 2004): p.134. Available at http://www.mapnetwork.org/reports/aids_in_asia.htm. 9. Human Rights Watch, Bangladesh, Ravaging the Vulnerable: Abuses Against Persons at High Risk of HIV Infection in Bangladesh 15/6 (C) (New York: Human Rights Watch, 2003). Available at http://www.hrw.org/reports/2003/ bangladesh0803/bangladesh0803.pdf; Human Rights Watch, Thailand, Not Enough Graves: The War on Drugs, HIV/AIDS, and Violations of Human Rights in Thailand 16/8 (C) (New York: Human Rights Watch, 2004). Available at http://hrw.org/reports/2004/thailand0704/thailand0704.pdf; XV International AIDS Conference Satellite Meeting, Human Rights at the Margins: HIV/AIDS, Prisoners, Drug Users and the Law (Proceedings Bangkok: July 9, 2004).

10. MAP (see note 8).

11. Human Rights Watch, Thailand, (see note 9), XV International AIDS Conference (see note 9).

12. Human Rights Watch (see note 9).

13. Data on HIV prevalence in prisons is difficult to obtain (generally because governments do not wish to release it), but where it has been documented, it is very high both in Africa and Asia. See, for example, University of Pretoria, HIV/AIDS and Human Rights in SADC, series of country reports on each of the SADC countries by the Centre for the Study of AIDS and Centre for the Study of Human Rights, University of Pretoria (2004); see also work by Penal Reform International, including a report on Health in Prisons (2001); Human Rights Watch, Thailand (see note 91. 
14. A human-rights based approach to HIV/AIDS has been part of the international response to the epidemic since the mid-1980s. It was endorsed by governments of the world at a special UN session on HIV/AIDS, when they made a commitment to tackle the epidemic and to "ensure the full enjoyment of all human rights and fundamental freedoms by people living with HIV/AIDS and members of vulnerable groups. ..." United Nations General Assembly Special Session on HIV/AIDS (UNGASS), Declaration of Commitment on HIV/AIDS, GA Res. S-26/2, 26th Sess. (2001). Subsequently, a special Reference Group was established to look at the interface between AIDS and human rights issues: UNAIDS Global Reference Group on HIV/AIDS and Human Rights, Public Report: First Meeting, January 23-24, 2003, Geneva, Switzerland. Despite these developments, the rights of marginal groups remain neglected, and a session documenting the detrimental effect of non-rights-based interventions for high-risk groups at the 2004 AIDS conference was incorporated only as a satellite session: XV International AIDS Conference, available at www.aids2004.org/.

15. US Department of State, Malawi Country Report on Human Rights Practices (Bureau of Democracy, Human Rights, and Labor, February 25, 2004).

16. Amnesty International, "Malawi," in Amnesty International Report 2005 (London, Amnesty International: 2005).

17. African Commission on Human and Peoples' Rights, Prisons in Malawi: Report of the Special Rapporteur on Prisons and Conditions of Detention in Africa: June 17-28, 2001 (IV/9 2001). Amnesty International (see note 16 ).

18. There are no published data for Pakistan, but our discussions with the NGO staff working with drug users there suggests the same types of abuses that have been documented in Bangladesh, including beatings and incarcerations. For data on Bangladesh, see Human Rights Watch, Ravaging the Vulnerable: Abuses Against Persons at High Risk of HIV Infection in Bangladesh 15/6 (C) (New York: Human Rights Watch, 2003). 19. Information in this paragraph was informed by the Pakistan entries to the following two publications: US Department of State, Pakistan Country Report on Human Rights Practices (released by the Bureau of Democracy, Human Rights and Labor, February 25, 2004); and Amnesty International, "Pakistan," in Amnesty International Annual Report 2005 (London: Amnesty International, 2005).

20. N. Haque, T. Zafar, H. Brahmbhatt, G. Imam, S. ul Hassan, and S. A. Strathdee, "High-Risk Behaviours Among Drug Users in Pakistan: Implications for Prevention of STDs and HIV/AIDS," International Journal of STD and AIDS 15/9 (2004): pp. 601-7. S. A. Strathdee, T. Zafar, H. Brahmbhatt, A. Baksh, and S. ul Hassan, "Rise in Needle Sharing Among Injecting Drug Users in Pakistan During the Afghanistan War," Drug and Alcohol Dependence 71/1 (2003): pp. 17-24.

21. See R. Horstman, J. Cleland, M. Douthwaite, M. Ambegaokar, and S. Salway, Monitoring and Evaluation of Sexual and Reproductive Health Interventions (London: London School of Hygiene and Tropical Medicine/Netherlands Interdisciplinary Demographic Institute [NIDI], 2002): p. 112. 
22. R. J. Cook, B. M. Dickens, and M. F. Fathalla (see note 6): p. 554; P. Hunt, Special Rapporteur on the Right to Health, Preliminary Report to the Commission on Human Rights, UN Doc. E/CN.4/2002/58 (2002), especially Section II, which points out the need for right to health indicators and benchmarks to monitor progressive realization. P. Hunt, Special Rapporteur on the Right to Health, First Interim Report to the UN General Assembly, UN Doc. A/58/427 (2003), in which a methodology for use of indicators in relation to the right to health is outlined.

23. J. Bruce, "Fundamental Elements of the Quality of Care: A Simple Framework," Studies in Family Planning 21/2 (1990): pp. 61-91.

24. J. Theis (see note 1).

25. J. Bertrand, R. Magnani, and N. Rutenberg, Handbook of Indicators for Family Planning Program Evaluation (Chapel Hill, NC: University of North Carolina, The Evaluation Project, 1994): p. 222.

26. P. Hunt, First Interim Report (see note 22).

27. African Commission on Human and Peoples' Rights (see note 17).

28. University of Pretoria, HIV/AIDS and Human Rights in Malawi (Pretoria: University of Pretoria, Centre for the Study of AIDS and Centre for the Study of Human Rights, 2004): p. 40.

29. African Commission on Human and Peoples' Rights (see note 17).

30. R. Cook, B. Dickens, and M. Fathalla (see note 6).

31. Government of Malawi, National HIV/AIDS Policy, Office of the President and Cabinet, National AIDS Commission (October 2003): paras 3.2.3, 5.8, and 5.10.

32. University of Pretoria (see note 28); US Department of State (see note 15).

33. F. Namangale, "Legalize Homosexuality Says Human Rights Body," The Daily News (Malawi) (January 28, 2005). Available at http://www. mask.org.za/SECTIONS/AfricaPerCountry/ABC/Malawi/Malawi_04.htm.

34. It is a constant claim of the religious right that condom promotion increases sexual activity. There are no substantive data to support this; there are, in fact, extensive data to indicate that condom promotion and sex education do not increase sexual activity. See, for example, $M$. Garvey, Dying to Learn: Young People, HIV and the Churches (London: Christian Aid, 2003). This document provides a review of literature and explicitly addresses Christian and other religious concerns and includes a powerful preface from the Archbishop of Cape Town.

35. UNAIDS, Pakistan Country Report (2004). Available at http://www. unaids.org/en/Regions_Countries/Countries/pakistan.asp.

36. S. A. Strathdee, T. Zafar, H. Brahmbhatt, A. Baksh, and S. ul Hassan (see note 20): pp. 17-24.

37. S. Panda, A. Chatteriee, S. K. Bhattacharya, B. Manna, P. N. Singh, S. Sarkar, T. N. Naik, S. Chakrabarti, and R. Detels, "Transmission of HIV from Injecting Drug Users to Their Wives in India," International Journal of STDs and AIDS 11/7 (2000): pp. 468-73; Monitoring the AIDS Pandemic (MAP) (see note 8 ).

38. MAP (see note 8); International Programs Center, Population Division, Drug Injecting and HIV/AIDS in Asia (Washington: US Bureau of the Census, 2005). 
39. N. Haque, T. Zafar, H. Brahmbhatt, G. Imam, S. ul Hassan, and S. A. Strathdee (see note 20); T. Zafar, H. Brahmbhatt, G. Imam, S. ul Hassan, S. A. Strathdee, "HIV Knowledge and Risk Behaviours Among Pakistani and Afghani Drug Users in Quetta, Pakistan," Journal of AIDS 32/4 (2003): pp. 394-8; UNAIDS, Epidemic Update (Geneva: December 2004): p. 87.

40. J. T. Bertrand and G. Escudero, "Compendium of Indicators for Evaluation of Reproductive Health Programs," MEASURE Evaluation Manual Series 6 (2002). Available at www.cpc.unc.edu/measure; Family Health International, Behavioral Surveillance Surveys (BSS), "Guidelines for Repeated Behavioral Surveys in Populations at Risk of HIV" (2000). Available at www.fhi.org; UNAIDS, National Aids Programmes: A Guide to Monitoring and Evaluation (2000), CD-ROM UNAIDS/00.17E. Available at www.cpc.unc.edu/measure. UNAIDS, United Nations General Assembly Special Session on HIV/AIDS (2002), Monitoring the Declaration of Commitment on HIV/AIDS Guidelines on Construction of Core Indicators. Available at www.unaids.org; WHO, National AIDS Programmes: A Guide to Monitoring and Evaluating HIV/AIDS Care and Support (Geneva: WHO, 2004): p. 82. Available at www.who.int/hiv/ pub/epidemiology/en/napyoungpeople.pdf.

41. These initiatives include work being done by the UN Special Rapporteur on the Right to Health (Paul Hunt), with a team of researchers at Essex University (UK). 